\title{
Abundance of thraustochytrids in coastal plankton
}

\author{
Takeshi Naganuma*, Hidemi Takasugi, Hiroyuki Kimura
}

Faculty of Applied Biological Science, Hiroshima University, 1-4-4 Kagamiyama, Higashi-Hiroshima 739-8528, Japan

\begin{abstract}
The abundance of thraustochytrids was investigated in and of the Seto Inland Sea, Japan Thraustochytrid cells were stained with acriflavine and counted directly by epifluorescence microscopy. Thraustochytrids were present in the water column at a density of $2.1 \times 10^{3}$ to $5.6 \times 10^{4} \mathrm{cells}^{-1}$ with an overall average of $1.0 \times 10^{4}$ cells $l^{-1}$, which was about $10^{-5}$ to $10^{-6}$ of the bacterioplankton abundance. In contrast to the low abundance of thraustochytrids, their biovolume was estimated to compose a not negligible fraction of marine microbiota, corresponding to about 3 to $43 \%$ of the bacterioplankton biovolume. Thus, it is suggested that thraustochytrids play an ecological role as alternative food sources for picoplankton feeders, as well as being active degraders and consumers in aquatic microbial food chains.
\end{abstract}

KEY WORDS: Thraustochytrid $\cdot$ Marine protoctista $\cdot$ Abundance $\cdot$ Biovolume

\section{INTRODUCTION}

Fungi and fungoid protoctists are important degradation agents in ecosystems, and their importance has been extensively investigated in terrestrial environments. On the other hand, fungoid protists in marine habitats are generally thought to be less important in abundance and contribution than bacteria. Marine fungi cause occasional problems in algal mariculture (Webber \& Thurman 1991), but they draw only limited attention in fish and invertebrate aquaculture (Austin 1988). Less attention has been given to the ecology of fungoid Protoctista, and consequently little information is available concerning organic degradation by their ectoenzymes (Chróst 1990). Yet, fungi are generally regarded to be more important than bacteria in the degradation of refractory substrates such as cell wall material and phenolic compounds (Valiela 1995, Newell 1996). Similarly, fungoid protoctists may play a role in decomposing refractory organic matter and thus enhance the carbon cycle in coastal waters (Bremer 1995, Bremer \& Talbot 1995).

Thraustochytrids are a common group of fungoid, Heterokonta protoctists (Cavalier-Smith et al. 1994) which are obligately halophilic (Moss 1986). Thrausto-

·E-mail: takn@ipc.hiroshima-u.ac.jp chytrids are found in saline lakes as well as marine and estuarine waters. Although thraustochytrid thalli, sporangia and resting spores are noted as being epi/endobiotic and sessile (Karling 1981, Rheinheimer 1991), some have been found in the water column (Schneider 1977. Moss 1986, Raghukumar et al. 1990). Recently, a rapid direct detection technique using the fluorogenic acriflavine dye was developed and used for the enumeration of particle-bound thraustochytrids (Raghukumar \& Schaumann 1993). Acriflavine differentiates thraustochytrids from other protists. Thraustochytrid cell walls and cell contents fluoresced red and bluegreen under blue excitation, respectively, while other protists fluoresced in different colors. However, no work has been published on the direct enumeration of planktonic thraustochytrids.

This communication reports the abundance of thraustochytrids in the Seto Inland Sea, Japan, which is a eutrophicated semi-enclosed area and has attracted many ecological and environmental studies (Okaichi \& Yanagi 1997). Thraustochytrids were shown to be present in the water column, with the biovolume composing an appreciable fraction of the marine microbiota. Thus, it is suggested that planktonic thraustochytrids play an ecological role as food sources for picoplankton feeders, in addition to the dual role of organic degradation and bacterivory (Raghukumar 1992). 


\section{MATERIALS AND METHODS}

Sample collection and site description. Water samples for thraustochytrid and bacterioplankton counting were collected with Van Dorn samplers during cruise no. 97-10 of RV 'Toyoshiomaru', 11 to 15 July 1997. The samples were collected from 3 depths $(1,5$ and $10 \mathrm{~m}$ deep) at a total of 14 sites; 11 in the Seto Inland Sea, Japan, and 3 just outside of an entrance to the sea (Fig. 1). The samplers were pre-washed and pre-rinsed with distilled water, and re-washed with the seawater taken from the same sampling site and depth immediately before sample collection. Water temperature, salinity, dissolved oxygen concentration and fluorescence intensity were measured at each station with a Sea Bird CTD. Concentration of chlorophyll a (chl a) was calculated from the fluorescence intensity by calibrating with chl a extracted in dimethyl formamide at $-20^{\circ} \mathrm{C}$.

Water temperature ranged from 20.3 (site 1, $10 \mathrm{~m}$ deep) to $25.9^{\circ} \mathrm{C}$ (site $15,1 \mathrm{~m}$ deep) among the sampling sites and depths. Salinity (psu) ranged from 23.36 (site $13,1 \mathrm{~m}$ deep) to 34.16 (site $4,10 \mathrm{~m}$ deep). Dissolved oxygen concentration was within the range of 3.50 (site 13,10 m deep) to $5.07 \mathrm{mg} \mathrm{O}_{2} \mathrm{l}^{-1}$ (site $16.1 \mathrm{~m}$ deep). It should be noted that the Seto Inland Sea and adjacent areas had a record rainfall from 7 to 13 July, when a total precipitation of $>170 \mathrm{~mm}$ was observed in the Osaka area (Osaka District Observatory 1997). Noctiluca and diatoms such as Thalassionema and Skeletonema were commonly dominant in the netcollected plankton populations.

Thraustochytrid and bacterial cell staining and counting. Thraustochytrid and bacterial cells were collected on pre-blackened polycarbonate filters (Isopore, Millipore; pore size, $0.2 \mu \mathrm{m}$; diameter, $25 \mathrm{~mm}$ ) immediately after water collection. Between 10 and $100 \mathrm{ml}$ of sample water was filtered for collecting thraustochytrid cells, and 0.3 to $1 \mathrm{ml}$ was filtered for bacterial cell counts. Counting in 20 to 30 microscopic fields was duplicated for each sample.

Thraustochytrid cells on filters were immediately stained with $4 \mathrm{ml}$ of $0.05 \%$ acriflavine (Sigma) in $0.1 \mathrm{M}$ citrate buffer ( $\mathrm{pH} \mathrm{3.0)}$ for $4 \mathrm{~min}$, and rinsed with $75 \%$ isopropanol for 1 min (Raghukumar \& Schaumann 1993). Distilled water was used to prepare acriflavine and isopropanol solutions. Staining was standardized with a culture of a thraustochytrid strain. The strain was isolated during abalone cell culture (Naganuma et al. 1996). The isolated strain was morphologically typical of the genus Thraustochytrium (Moss 1986), which was often found in abalone cell cultures and caused the demise of the molluscan cell cultures (Naganuma et al. 1994). The strain was maintained in the laboratory with $0.98 \%$ sodium glutamate and $0.02 \%$ sodium inosinate in artificial seawater (Marine Art SF, Senju Seiyaku Co. Ltd, Osaka, Japan). It is very tentatively suggested that the strain is related to the species $T$. multirudimentale, based on the agar-plate culture, though further taxonomic study has not been carried out.

Bacterial cells on filters were stained with $0.01 \%$ acridine orange in $10 \mathrm{mM}$ phosphate buffer ( $\mathrm{pH} 8.0$ ) (Hobbie et al. 1977). The filters were air-dried and kept in a freezer ( $\left.\mathrm{ca}-10^{\circ} \mathrm{C}\right)$ until microscopically examined.

The stained cells were counted with epifluorescence microscopes (Zeiss Axiovert 135 and Olympus $\mathrm{BH}-2)$ under violet-blue excitation. Acriflavine stains both nuclear DNA and cell wall sulfated polysaccharides, fluorescing green and red, respectively. Thraustochytrid cells fluoresced red and green, and thus were distinguished from other protoctists fluorescing green only (Raghukumar \& Schaumann 1993). UV excitation was also used to differentiate thrausto-

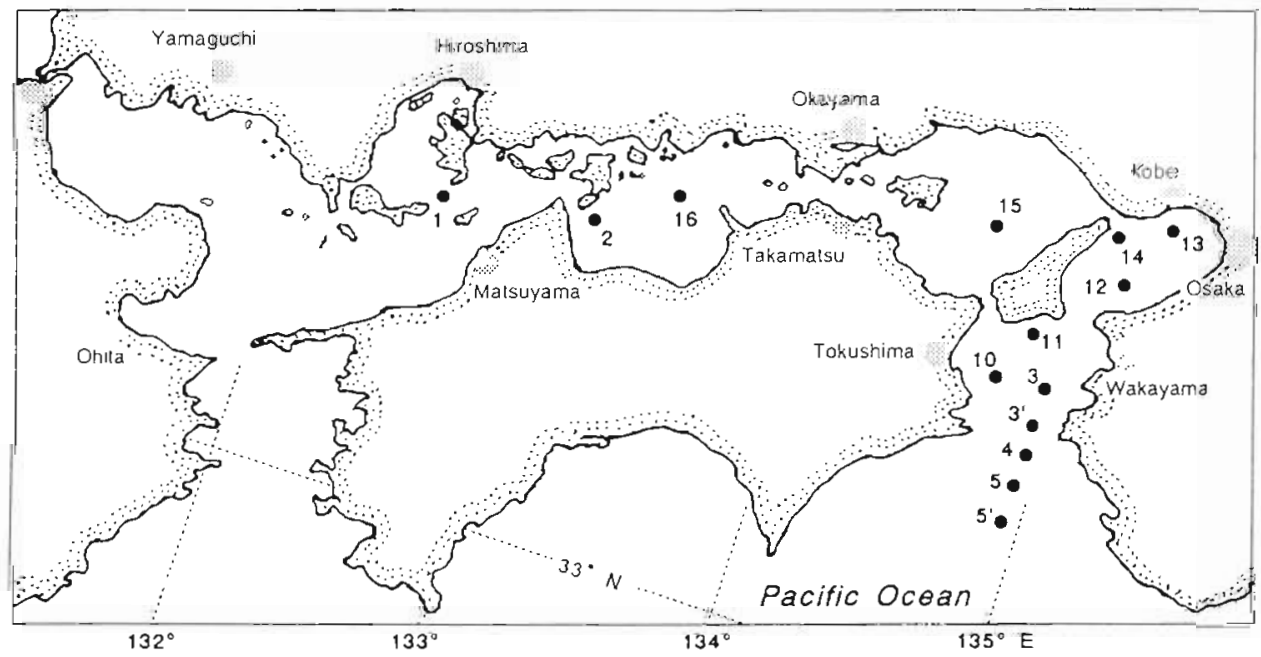

Fig. 1 Sites of sample collection in and near the Seto Inland Sea, Japan 
chytrids from photosynthetic protists fluorescing red under UV excitation.

The limit of the current staining technique is that zoospores of most thraustochytrid species lack cell wall (Moss 1986). Also, very small cells $(<5 \mu \mathrm{m})$ were not well distinguishable because the cell wall-associated red fluorescence was weaker than the nucleus-associated green fluorescence. Thus the very small cells were not counted, and the counts reported in this study are likely to be underestimations. On the other hand, there is a possibility of overestimation by counting non-thraustochytrids that have sulfated polysaccharides in their cell walls. Although only limited numbers of false-positive but morphologically distinguishable cells were observed, there still remains a possibility of these being present in the samples.

\section{RESULTS AND DISCUSSION}

\section{Abundance of thraustochytrids}

Thraustochytrids were found in the water column (Fig 2) at a population density ranging from 2.1 ( $\pm \mathrm{SD} 4.19$ ) $\times$ $10^{3}$ cells $^{-1}$ (site $10,10 \mathrm{~m}$ deep) to 5.6 $( \pm \mathrm{SD} 8.4) \times 10^{4}$ cells $\mathrm{l}^{-1}$ (site $12,1 \mathrm{~m}$ deep), with the overall average of 1.03 $( \pm \mathrm{SD} 1.10) \times 10^{4}$ cells $^{-1}$ (Table 1 ). The largest standard deviations (SD) were due to the variation in counting thraustochytrids at $<10$ cells per microscopic fields. Increased filtration volume and microscopic fields would have decreased the SD values. Despite the large $\mathrm{SD}$, the thraustochytrid counts were correlated with the abundances of bacterioplankton and phytoplankton, thus indicating a general relationship among them (Table 2; see next section)

Table 1 Average abundance of thraustochytrids, bacterioplankton and phytoplankton (chl a)

\begin{tabular}{|lccc|}
\hline & $\begin{array}{c}\text { Thraustochytrids } \\
\left(\times 10^{3} \text { cells } ~^{-1}\right)\end{array}$ & $\begin{array}{c}\text { Bacterioplankton } \\
\left(\times 10^{8}{\left.\text { cells } ~^{-1}\right)}\right.\end{array}$ & $\begin{array}{c}\text { Phytoplankton } \\
\left(\mu \mathrm{chl}^{-1}\right)\end{array}$ \\
\hline Overall $(\mathrm{n}=42)$ & $10.3 \pm 11.0$ & $5.50 \pm 2.06$ & $14.88 \pm 13.51$ \\
$1 \mathrm{~m}(\mathrm{n}=14)$ & $14.4 \pm 16.4$ & $6.09 \pm 1.57$ & $20.69 \pm 17.71$ \\
$5 \mathrm{~m}(\mathrm{n}=14)$ & $9.5 \pm 7.9$ & $5.99 \pm 2.20$ & $14.72 \pm 11.82$ \\
$10 \mathrm{~m}(\mathrm{n}=14)$ & $7.0 \pm 4.4$ & $4.42 \pm 2.03$ & $9.24 \pm 7.19$ \\
\hline
\end{tabular}

Previous studies reported thraustochytrid abundance of up to $1.1 \times 10^{3}$ cells $1^{-1}$ in the coastal Arabian Sea (Raghukumar et al. 1990 ) and to $1.5 \times 10^{3}{\text { cells } 1^{-1}}^{-1}$ in coastal North Sea water, counted as 'infectious entities' (Schneider 1977). These counts were based on cultivation, and thus the counts were predictably lower than the direct enumeration in this study. No published work on direct enumerations of thraustochytrids in water columns is available, so no comparisons can be made with the data obtained in this study. Generally, the numbers of thraustochytrids were high in the surface $1 \mathrm{~m}$ of water and decreased with the depth, with some minor reversals (Table 1, Fig. 1). High numbers $\left(>10^{4}\right.$ cells $\left.1^{-1}\right)$ were typically found in Hiroshima Bay (site 1), and 
Table 2. Correlation coefficients among thraustochytrids (thra), bacterioplankton (bact) and phytoplankton (chl a) (n = 42). Significance: $p<<0.05, \cdots p<0.01, \cdots p<0.001$

\begin{tabular}{|lccc|}
\hline & thra vs bact & thra vs chl a & chl a vs bact \\
\hline $\begin{array}{l}\text { Linear eq. } \\
(Y=\mathrm{a} X+\mathrm{b})\end{array}$ & $0.439 \cdots$ & $0.432 \cdots$ & 0.259 \\
$\begin{array}{l}\text { Allometric eq. } \\
\left(Y=\mathrm{a}^{\mathrm{b}}\right)\end{array}$ & $0.599 \cdots$ & $0.504 \cdots$ & $0.348^{\circ}$ \\
\hline
\end{tabular}

in Osaka Bay (sites 12 to 14), and the adjacent Kii Channel (site 11) and Harima-nada (site 15). These areas are known to be highly eutrophicated (Okaichi \& Yanagi 1997). The count at $1 \mathrm{~m}$ depth at site 13 was relatively low for Osaka Bay. This was probably due to the increased discharge of river water, as indicated by the low salinity $(23.36 \mathrm{psu}$ ) which was the lowest in this study. It is likely that the thraustochytrids in the surface water were washed out by the river inflow. Also, thraustochytrids are obligately halophilic (Moss 1986) and thus they were possibly inactive at such low salinity.

\section{Correlation with bacterio- and phytoplankton abundances}

The abundance of planktonic thraustochytrids was positively correlated with the abundances of bacterioand phytoplankton (Table 2). Highly significant correlations ( $p<0.001$ ) were yielded by allometric equations $\left(Y=\mathrm{a} X^{\mathrm{b}}\right)$; the correlations by linear equations $(Y=\mathrm{a} X+$ b) were lower but still significant ( $p<0.01)$ The greater parts of the data were below the overall averages (29/42 for thraustochytrids; $26 / 42$ for bacterioplankton; and $27 / 42$ for chl a), which were more weighted in the allometric equations. This explains, at least in part, the higher correlation coefficients yielded by the allometric equations.

The thraustochytrid abundance was more strongly correlated with the abundance of bacterioplankton than with phytoplankton by both equations. The closer correlation of thraustochytrids and bacterioplankton may be a reflection of bacterivory by thraustochytrids (Raghukumar 1992). In contrast, Schneider (1977) suggested that high thraustochytrid abundance is correlated to low bacterioplankton abundance. A simple explanation may be that the thraustochytrid and bacterioplankton abundances are not in synchrony over time. Positive and negative correlations can be drawn from a single 'prey-predator' system, depending on the phase-lag between the trophic levels (trophodynamic phasing; e.g. Parsons 1988), and the duration of the phase-lag is variable. The trophodynamic coupling of thraustochytrids and bacterioplankton should be studied in more detail in the future by comparing the production rates.

Correlation between the thraustochytrid abundance and chl a concentration suggests that this planktonic fungal group depends, at least to some extent, on the exudate dissolved organic matter (DOM) from phytoplankton, or on degradation of phytodetritus. However, the bacterio- and phytoplankton abundances were less correlated, though close coupling was shown in the previous study (Naganuma \& Miura 1997). Bacterioplankton dynamics are highly responsive to the release of photosynthetically produced DOM (e.g. Cole et al. 1982, Chrost \& Faust 1983) and thus easily influenced by environmental perturbations such as heavy rain just before sample collection. On the other hand, the thraustochytrids-to-phytoplankton relationship is likely loose and slow, and thus does not rapidly respond to increases and decreases of phytoplankton activity. Again, production-based studies are needed to analyze the presumed thraustochytrid/phytoplankton coupling.

\section{Ecological implications}

The ratio of planktonic thraustochytrid abundance to bacterioplankton abundance was as low as $10^{-5}$ to $10^{-6}$ (Fig. 2). In comparison, the ratio from particle-bound populations was $10^{-2}$ to $10^{-5}$ (Raghukumar \& Schaumann 1993). As thraustochytrids are epibiotically abundant (Karling 1981), it is reasonable to expect the ratio from the particle-bound populations to be larger than that from the planktonic populations. The abundance of planktonic thraustochytrids was 3 to 4 orders of magnitude lower than that of heterotrophic nanoflagellates (average $43 \mathrm{\mu m}^{3}$ ) in the Seto Inland Sea (Iwamoto et al. 1994), but 10 times larger than that of the ciliate microzooplankton in the same area $\left(10^{3}\right.$ to

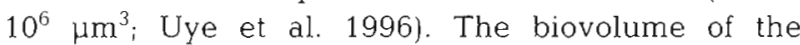
observed thraustochytrids was approximately 65 to $4200 \mu \mathrm{m}^{3}$, assuming a spherical shape with a diameter of 5 to $20 \mu \mathrm{m}$. These biovolumes suggest that thraustochytrids are not necessarily only a minor component of marine microbial communities. Although this comparison ignores the seasonal and yearly variation, it gives us a general idea about the biovolume ratios among the planktonic groups.

Observed thraustochytrids were mostly unicellular, globose to subglobose, and sized 5 to $20 \mu \mathrm{m}$ in diameter. In comparison, the diameter of particle-bound thraustochytrids ranges from 3.5 to $19.7 \mu \mathrm{m}$ (Raghukumar \& Schaumann 1993). Taking $10 \mu \mathrm{m}$ as the average diameter of the observed thraustochytrids (geometric 
average of 5 and $20 \mu \mathrm{m}$ ), the average cellular biovolume is estimated to be about $524 \mu^{3}$. Assuming the cellular biovolume of the bacterioplankton to be $0.1 \mathrm{\mu m}^{3}$ (Naganuma \& Miura 1997), total biovolume (i.e. cellular biovolume times cell number) of the planktonic thraustochytrids corresponds to about $9 \%$ on average of that of bacterioplankton, which should not be negligible in marine microbial ecology. The ratio ranges from about $3 \%$ (site $5,5 \mathrm{~m}$ deep) to $43 \%$ (site $12,1 \mathrm{~m}$ deep), and, strikingly, sites 5 and 12 were ranked as the least and most eutrophicated sites in this study, respectively. Thus the thraustochytrid/bacterioplankton biovolume ratio may serve as an indicator of water quality.

The biomass of the thraustochytrid population was not estimated due to the lack of information about cellular biomass. Thraustochytrids were once regarded as lower fungi. However, recent molecular studies have indicated that thraustochytrids are more closely related to brown algae and diatoms (Cavalier-Smith et al. 1994). Fungi, brown algae, and diatoms generally have a $\mathrm{C} / \mathrm{N}$ ratio of 10,16 to 68 , and 6.5 , respectively (Valiella 1995). Although the $\mathrm{C} / \mathrm{N}$ ratio of thraustochytrids has not yet been determined, it is likely to be higher than the bacterial $\mathrm{C} / \mathrm{N}$ ratio of 5.7 (Valiella 1995). Therefore the importance of thraustochytrids in carbon cycling may be greater than would be inferred from their abundance and biovolume.

Planktonic thraustochytrids, 5 to $20 \mu \mathrm{m}$ in diameter, are likely a suitable food item for protozoans (Fenchel 1980, Rassoulzadegan et al. 1988), heterotrophic dinoflagellates (Hansen 1992, Hansen et al. 1996), and filter-feeding bivalves (Jørgensen 1996). Thraustochytrids may provide an alternative food for picoplankton feeders, particularly in eutrophicated waters where thraustochytrid abundance is high.

Marine fungi are generally thought to be effective in the degradation of refractory substrates such as cell wall material and phenolic compounds (Bremer 1995. Bremer \& Talbot 1995, Valiela 1995). It has been shown that a certain fraction of DOM in the ocean is terrigenous or old-aged, both of which are refractory (Meyers-Schulte \& Hedges 1986, Aluwihare et al. 1997, Opsahl \& Benner 1997). In the degradation of refractory DOM, planktonic fungoid protists may play a key role in increasing bioavailability of the DOM and thus enhancing the carbon cycle in the ocean. Also, improved DOM bioavailability would allow the increase in bacterial secondary production, which often exceeds the primary production (Krstulovic et al. 1995, Naganuma \& Miura 1997). Therefore, marine fungoid protists such as thraustochytrids are potentially important alternative food sources and enhancers of bacterial production.
Acknowledgements. The authors are grateful to the crew of the RV 'Toyoshiomaru', Hiroshima University, for the onboard assistance. Prof. S. Uye, Hiroshima University, kindly offered the opportunty for sample collection during the 'Toyoshiomaru' cruise. This work was partly supported by the Steel Industry Foundation for the Advancement of Environmental Protection Technology.

\section{LITERATURE CITED}

Aluwihare LI, Repeta DJ, Chen RF (1997) A major biopolymeric component to dissolved organic carbon in surface sea water. Nature 387:166-169

Austin B (1988) Marine microbiology. Cambridge University Press, Cambridge

Bremer GB (1995) Lower marine fungi (Labyrinthulomycetes) and the decay of mangrove leaf litter Hydrobiologia 295 $89-95$

Bremer GB, Talbot G (1995) Cellulolytic enzyme activity in the marine protist Schizochytrium aggregatum. Bot Mar $38: 37-41$

Cavalier-Smith T, Allsopp MTEP, Chao EE (1994) Thraustochytrids are chromists, not fungi: 18S rRNA signature of Heterokonta. Phil Trans R Soc Lond B 346:387-397

Chróst RJ (1990) Microbial ectoenzymes in aquatic environments. In Overbeck J, Chróst RJ (eds) Aquatic microbial ecology. Springer-Verlag, New York, p 47-78

Chrost RH, Faust MA (1983) Organic carbon release by phytoplankton: its composition and utilization by bacterioplankton. J Plankton Res 5:477-493

Cole JJ, Likens GE, Strayer DL (1982) Photosynthetically produced dissolved organic carbon an important carbon source for planktonic bacteria. Limnol Oceanogr 27:1080-1090

Fenchel T (1980) Relation between particle size selection and clearance in suspension-feeding ciliates. Limnol Oceanogr 25:733-738

Hansen FC, Witte HJ, Passarge J (1996) Grazing in the heterotrophic dinoflagellate Oxyrrhis marina: size selectivity and preference for calcified Emiliania huxleyi cells. Aquat Microb Ecol 10:307-313

Hansen PJ (1992) Prey, size selection, feeding rates and growth dynamics of heterotrophic dinoflagellates with special emphasis on Gymnodinium spirale. Mar Biol 114: $327-334$

Hobbie JE, Daley RJ, Jasper S (1977) Use of Nuclepore filters for counting bacteria by fluorescence microscopy. Appl Environ Microbiol 33:1225-1228

Iwamoto N, Imai I, Uye S (1994) Seasonal fluctuation in abundance of bacteria, heterotrophic nanoflagellates, autotrophic nanoflagellates and nanodiatoms in Hiroshima Bay, the Inland Sea of Japan. Bull Plankton Soc Jap 41: $31-42$

Jørgensen CB (1996) Bivalve filter feeding revisited. Mar Ecol Prog Ser 142:287-302

Karling JS (1981) Predominantly holocarpic and eucarpic simple biflagellate phycomycetes. J Cramer, Vaduz

Krstulovic N, Pucher-Petkovic T, Solic M (1995) The relation between bacterioplankton and phytoplankton production in the mid Adriatic Sea. Aquat Microb Ecol 9:41-45

Meyers-Schulte KJ, Hedges JI (1986) Molecular evidence for a terrestrial component of organic matter dissolved in ocean water. Nature 321:61-63

Moss ST (1986) Biology and phylogeny of the Labyrinthuales and Thraustochytoriales. In: Moss ST (ed) The biology of marine fungi. Cambridge University Press, Cambridge, p $105-129$ 
Naganuma T, Akutsu T, Ishida T, Kato C, Horikoshi K (1996) In situ RT-PCR from the b-tubulin mRNA in abalone cells in primary cultures. J Mar Biotechnol 4:75-81

Naganuma T, Degnan BM, Horikoshi K, Morse DE (1994) Myogenesis in primary cell cultures from larvae of the abalone Haliotis rufescens. Mol Mar Biol Biotechnol 3:131-140

Naganuma T, Miura S (1997) Abundance, production and viability of bacterioplankton in the Seto Inland Sea, Japan. J Oceanogr 53: in press

Newell SY (1996) Established and potential impacts of eukaryotic mycelial decomposers in marine/terrestrial ecotones. J Exp Mar Biol Ecol 200:187-206

Okaichi T, Yanagi $T$ (eds) (1997) Sustainable development in the Seto Inland Sea, Japan. Terra Scientific Publishing Co, Tokyo

Opsahl S, Benner R (1997) Distribution and cycling of terrigenous dissolved organic matter in the ocean. Nature 386 : $480-482$

Osaka District Observatory (1997) Osaka District Observatory Monthly Report, July 1997

Parsons TR (1988) Trophodynamic phasing in theoretical, experimental and natural pelagic ecosystems. J Oceanogr Soc Jap 44:94-101

Raghukumar S (1992) Bacterivory: a novel dual role for

Editorial responsibility: Otto Kinne (Editor),

Oldendorf/Luhe, Germany thraustochytrid fungi in the sea. Mar Biol 113:165-169

Raghukumar S, Raghukumar C, Rajendran A (1990) Abundance of thraustochytrid fungi in the Arabian Sea. Estuar Coast Shelf Sci 31:351-358

Raghukumar S, Schaumann K (1993) An epifluorescence microscopy method for direct detection and enumeration of the fungi-like marine protists, the thraustochytrids Limnol Oceanogr 38:182-187

Rassoulzadegan F, Laval-Peuto M, Sheldon RW (1988) Partitioning of the food ration of marine ciliates between picoand namoplankton. Hydrobiologia 159:75-88

Rheinheimer G (1991) Aquatic microbiology, 4th edn. John Wiley \& Sons, Chichester

Schneider J (1977) Fungi. In: Rheinheimer G (ed) Microbial ecology of a brackish water environment. SpringerVerlag, Berlin, p 90-102

Uye S, Nagano N, Tamaki H (1996) Geographical and seasonal variations in abundance, biomass and estimated production rates of microzooplankton in the Inland Sea of Japan. J Oceanogr 52:689-703

Valiela I (1995) Marine ecological processes, 2nd edn. Springer-Verlag, New York

Webber HH, Thurman HV (1991) Marine biology, 2nd edn. Harper Collins Publishers, New York

Submitted: September 8, 1997; Accepted: December 17, 1997 Proofs received from author(s): February 3, 1998 